\title{
AN EYELESS SUBTERRANEAN BEETLE \\ (PSEUDANOPHTHALMUS) \\ FROM A KENTUCKY COAL MINE \\ (COLEOPTERA: CARABIDAE: TRECHINAE)*
}

\author{
BY THOMAS C. BARR, JR. \\ School of Biological Sciences, \\ University of Kentucky \\ Lexington, Kentucky 40506
}

The trechine genus Pseudanophthalmus includes approximately 240 species from caves of the Appalachian valley, Mississippian plateaus, and Bluegrass and Central Basin regions of eastern United States. Although the model of cave trechine speciation which I have developed for this fauna (Barr, 1967a, 1968, 1981, 1985) requires a two-step process of 1) local diversification in deep soil and 2) subsequent isolation in nearby caves, the first stage was postulated on the basis of an abundant edaphobitic trechine fauna in Europe and elsewhere (see Jeannel, 1926-1930, for example). In eastern United States a single species of Pseudanophthalmus has been described from a non-cave habitat: $P$. sylvaticus occurs deep in the soil under large stones in mountain forests near Marlinton, West Virginia (Barr, 1967b).

Existing distributions of cave Pseudanophthalmus species strongly suggest an ancestral Pleistocene refugium in the mixed mesophytic forests of the Allegheny plateau (Barr, 1981, 1985). The distinctly different lineages occupying caves of the Appalachian valley to the east of the plateau and those of the Interior Low Plateaus to the west of the Alleghenies indicate substantial local differentiation prior to cave colonization (Barr, 1981); the geographic clustering of related species suggests vicariance among cave descendants of these locally differentiated edaphobites (Barr, 1965, 1981, 1985).

An integrated phylogeny of Pseudanophthalmus has thus far proven elusive, as though key pieces of a jigsaw puzzle were missing. Preliminary track analysis at the species group level thus shows a

*Manuscript received by the editor December 15, 1985 
void in the Allegheny plateau, with only the gracilis (east) and inexpectatus (west) groups clearly related by synapomorphic characters. The engelhardti group (s. str., see Barr, 1981) does track through the Allegheny plateau, but only via the Tennessee River gorge west of Chattanooga. The large, pubescent, riparian species of the tenuis group (IN, IL, KY) are superficially and ecologically similar to the species of the grandis group (chiefly eastern WV), but there are insufficient synapomorphies to provide substantive support to an hypothesis of taxonomic affinity (Barr, 1985). It is tempting to speculate that transitional species or species groups occupied the non-limestone terranes of the interior of the Allegheny plateau. If these transitional forms are extinct, no sound phylogeny of Pseudanophthalmus may be possible. No caves occur in the thick sequences of clastic rocks-sandstones, conglomerates, coals, and shales-in this region. But if ancestral edaphobitic beetles are hypothetically invoked throughout the Pleistocene to supply the caves on either side of the Alleghenies, why should they suddenly become extinct after Wisconsinan glaciation? Could some of these obligate soil inhabitants still survive in deep, forest floor soil of this region? The discovery of $P$. sylvaticus suggested that this could indeed be the case, but two decades have elapsed without further edaphobitic trechines being found.

Juberthie et al. (1980) demonstrated that "troglobitic" arthropods exist in the "milieu souterrain superficiel" of non-karst regions in southern France. At the interface between the soil mantle and the bedrock there are air-filled pockets-microcaverns-from which these authors have trapped several species of millipedes and beetles (including trechines) that are for all intents and purposes "troglobites," even in non-calcareous terranes. However, attempts to trap such organisms in eastern United States have met with failure. Suitable sites for trap insertion in France or Japan are in areas of fractured rock (C. Juberthie and S.-I. Uéno, pers. comm.), unlike the majority of karst regions in eastern United States. The traps are baited pitfall traps containing Galt's solution or equivalent; they are placed about $1 \mathrm{~m}$ below the surface, buried, and checked at intervals of 2-4 weeks.

On October 18, 1985, J. R. MacGregor and H. D. Bryan collected 2 female Pseudanophthalmus specimens in an abandoned coal mine 
in Floyd County, eastern Kentucky. The mine portal, designated "D-104" in MacGregor's notes, is located at Bosco (= Hueysville), about $22 \mathrm{~km}$ SSW Prestonsburg. The beetles were found in a muddy spot on the mine floor under rocks.

These two females are identical with females of Pseudanophthalmus hypolithos (Barr, 1981: 83, figs. 28, 34), a species previously known only from Old Quarry Cave, in Pine Mountain, near Ashcamp, Pike County, Kentucky, $45 \mathrm{~km}$ SE of the Bosco mine. The hypolithos group, which includes 4 species from Pine Mountain, $\mathrm{KY}$, and a single species ( $P$. praetermissus) near the base of Cumberland Mountain in Scott County, VA, belongs to the engelhardti complex, a group of 55 largely Appalachian valley species arranged in 7 species groups (Barr, 1981). Pseudanophthalmus hypolithos, itself, is distinguished from other species of the group by quite deep elytral striae and convex elytral intervals, greatly reduced pubescence limited chiefly to sparse and very short rows on each elytral interval, and falciform aedeagal apex. The aedeagal character could not be checked, but based on my experience with species of the genus, the absence of non-genitalic differences is decisive; only 2/240 species are determined solely on male genitalic characters.

Previously I had considered Pine Mountain as a "karst island" within the Allegheny plateau; it is a fault block about $125 \mathrm{~km}$ long, extending from Elkhorn City, Kentucky, southwest to Campbell County, Tennessee, with a band of Newman limestone (Mississippian) exposed on its northwest face. To the extent that "troglobitic" Pseudanophthalmus species are collectable within the caves of Pine Mountain, this is still true after a fashion, but the discovery of $\boldsymbol{P}$. hypolithos in a coal mine indicates that "caves" are a somewhat artificial concept in terranes where highly fractured rocks (shales, coals, conglomerates) exist, and that "troglobitic" trechines may occur over a wider area than is strictly delimited by karst terrane. The Bosco mine offers another sort of entry into the deep soil community, and the discovery of $\boldsymbol{P}$. hypolithos there is a strong impetus to search for other edaphobitic trechines within the interior of the Allegheny plateau.

\section{ACKNOWLEDGEMENTS}

I thank John R. MacGregor for making these specimens available for study. This paper was supported in part by NSF DEB-8202339. 


\section{Literature Cited}

BARR, ThOMAS C., JR.

1965. The Pseudanophthalmus of the Appalachian valley (Coleoptera: Carabidae: Trechini). Amer. Midl. Nat. 73: 41-72.

1967a. Observations on the ecology of caves. Amer. Nat. 101: 475-492.

1967b. A new Pseudanophthalmus from an epigean environment in West Virginia (Coleoptera: Carabidae). Psyche 74: 166-174.

1968. Cave ecology and the evolution of troglobites. Evolutionary Biology 2: 45-102. Appleton-Century-Crofts, New York.

1981. Pseudanophthalmus from Appalachian caves (Coleoptera: Carabidae): the engelhardti complex. Brimleyana, no. 5: 37-94.

1985. Pattern and process in speciation of trechine beetles in eastern North America (Coleoptera: Carabidae: Trechinae). IN G. E. Ball, ed., Taxonomy, Phylogeny, and Zoogeography of Beetles and Ants. Dordrecht, Netherlands: Dr. W. Junk Publishers.

JEANNEL, RENE

1926-1930. Monographie des Trechinae: Morphologie comparée et distribution d'un groupe de Coléoptères. L'Abeille 32: 221-550; 33: 1-592; 34: 59-122; 35: 1-808.

Juberthie, C., B. Delay, and M. Boulllon

1980. Extension du milieu souterrain en zone non-calcaire: déscription d'un nouveau milieu et de son peuplement par les Coléoptères troglobies. Mém. Biospéol. 7: 19-52. 

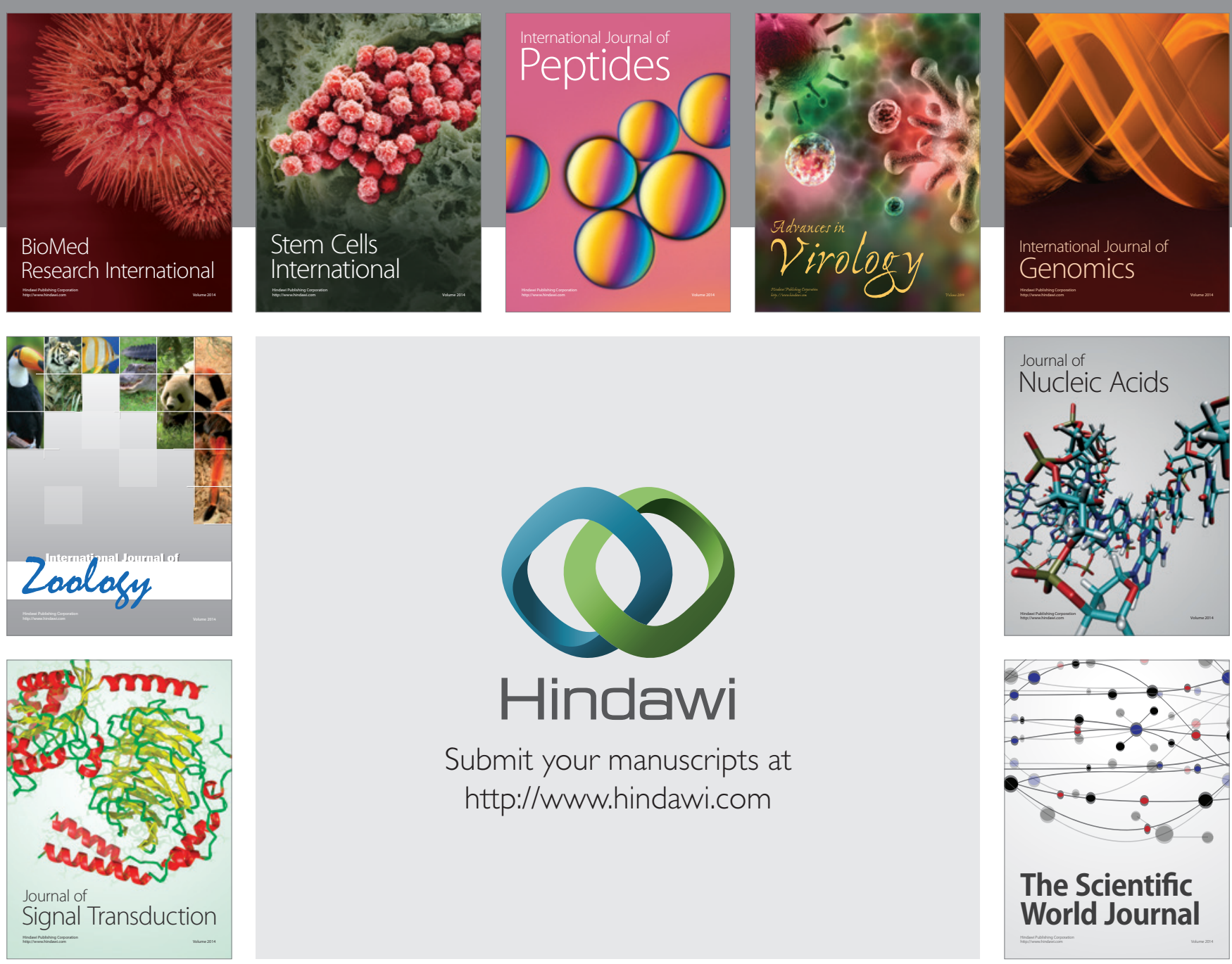

Submit your manuscripts at

http://www.hindawi.com
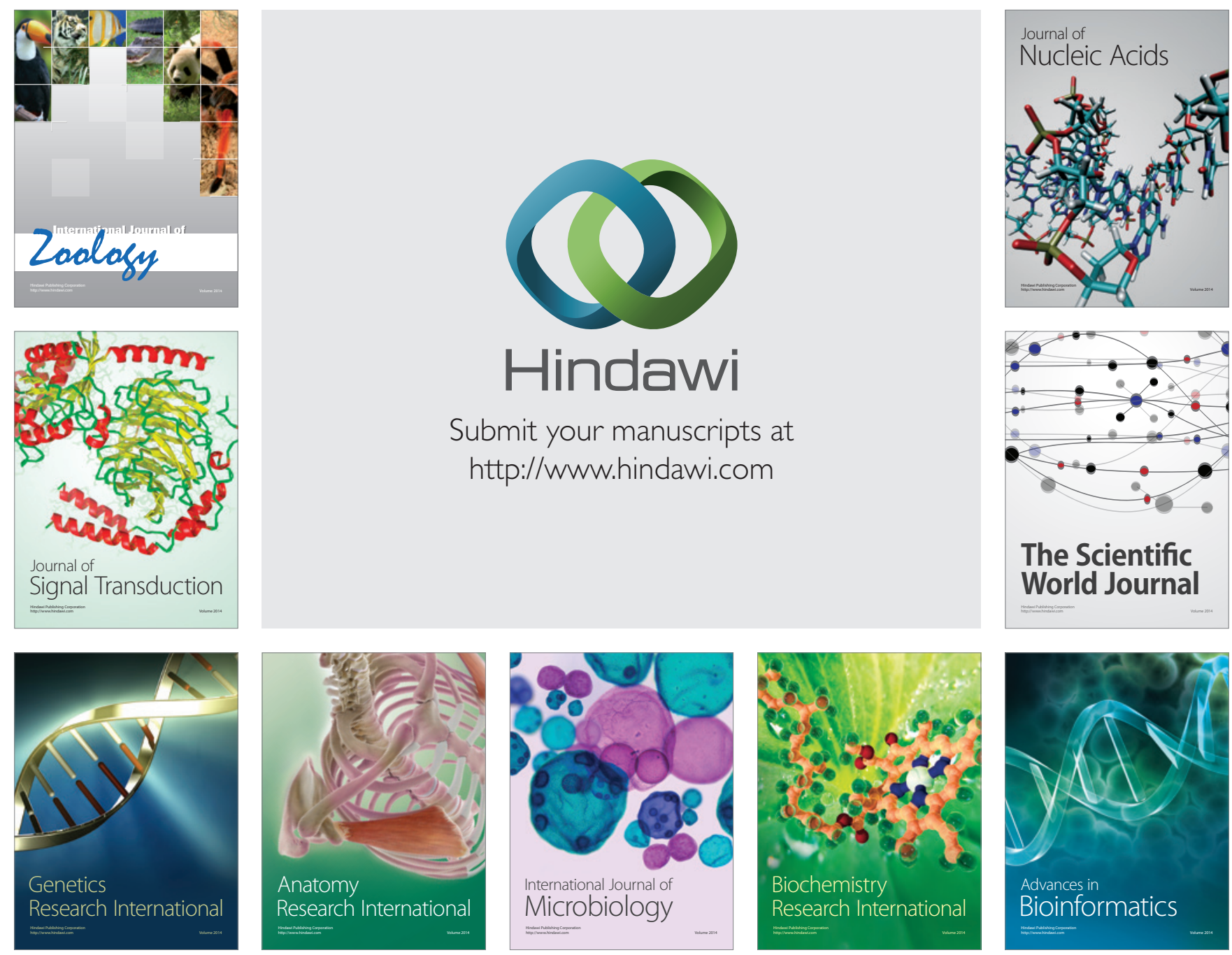

The Scientific World Journal
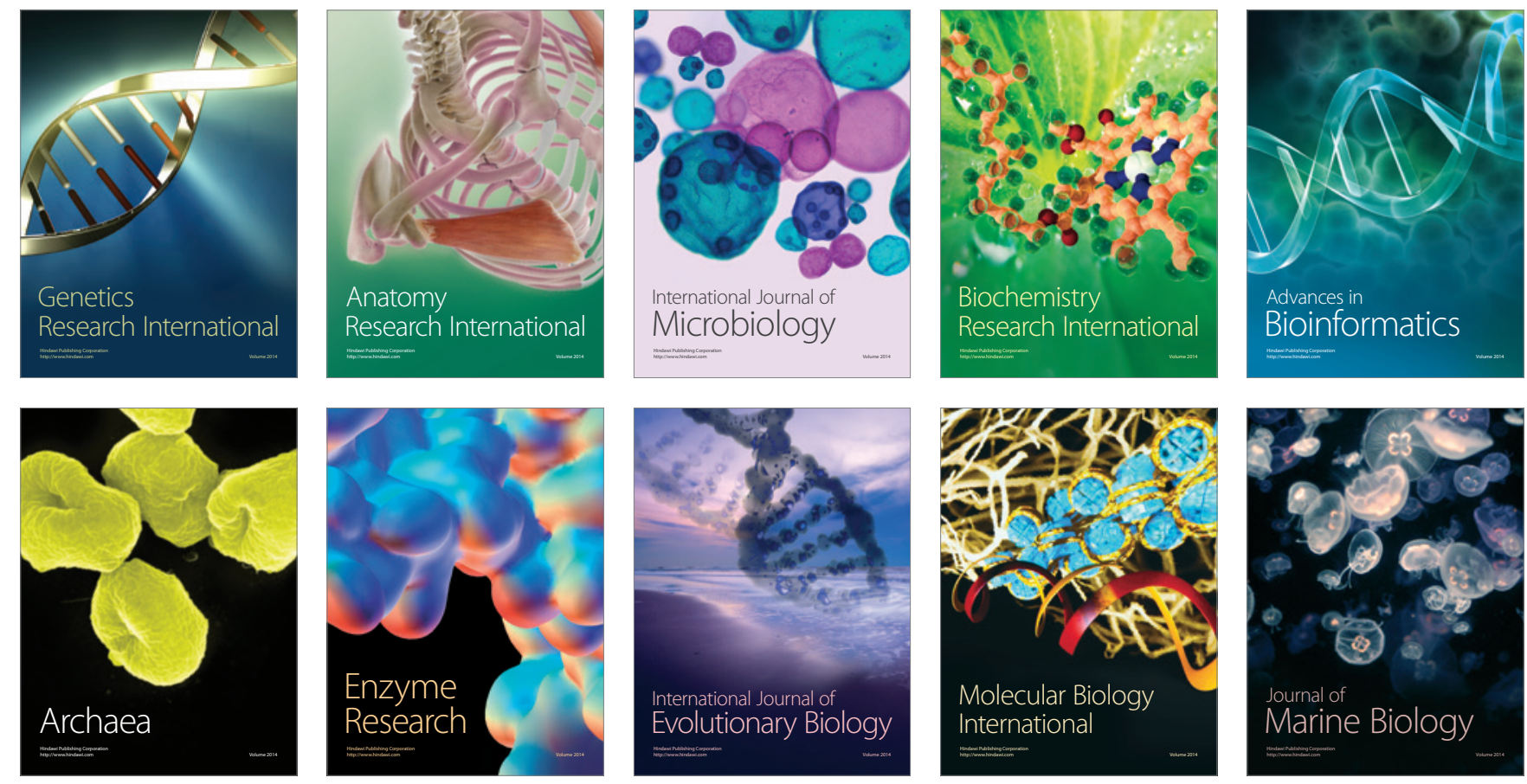